\title{
Physical and Mechanical Properties of Paricá Wood Species Treated with CCB Preservative
}

\author{
Fe lipe H. Icimoto ${ }^{1}$, Fabiane S. Ferro ${ }^{1}$, Luciano D. Varanda ${ }^{1}$, Amós M. de Souza ${ }^{1}$, Diego H. de Almeida ${ }^{2}$, \\ André L. Chris toforo ${ }^{3, *}$, Francis co A. Rocco Lahr ${ }^{2}$ \\ ${ }^{1}$ Department of Science and En gineering Materials, En gineering School of São Carlos (EESC/USP), São Carlos, 13566-590, Brazil \\ ${ }^{2}$ Department of Structural Engineering, En gin eering School of São Carlos (EESC/USP), São Carlos, 13566-590, Brazil \\ ${ }^{3}$ Department of Mechanical En gin eering, Federal Univ ersity of São João del-Rei, São João del-Rei, 36307-352, Brazil
}

\begin{abstract}
Wood of Paricá species (Schizolobium amazonicum) is highly susceptible to degradation by decay microorganis ms. Due to its increasing production in the northern region of Brazil, about 85 thousand hectares, and later use both for structural purposes and for the furniture industry, the need of extending life of Paricá wood applying chemical preservatives arises. One current alternative is the treatment by autoclave using CCB (Copper Chro me Boron). The aim of this study was to evaluate the influence of treatment with CCB in the properties: apparent density, parallel and perpendicular hardness to the grain, strength to shear and in the compression parallel to the grain of the Schizolobium amazonicum wood species, comparing the results with untreated wood. We observed that treatment with CCB did not change the properties of apparent density, shear strength, perpendicular hardness, strength and stiffness in co mpression parallel to the grain. For the hardness strength parallel to the grain was decreased in $28.9 \%$.
\end{abstract}

Keywords Paricá, Treated Wood, CCB, Physical and Mechanical Properties

\section{Introduction}

The growth of world demand for timber implies the search for new species of fast growth and silvicultural potential in this scenario, native species, generally, are advantageous in adaptability[1].

In 1948, through Forest Service State of São Paulo, were introduced to test the American species known in the sources as "yellow pine" which include $P$. palustris, $P$. echinata, $P$. elliottii and P. taeda. Among these, the last two highlighted for ease cultivation, rapid growth and intense reproduction in the South and Southeast of Brazil. Since then, a large number of species continued to be introduced and established in field experiments by government agencies and private enterprises, aiming commercial plantations [2].

According to ABRAF- Brazilian Association of Planted Forest Producers[3], in 2010, the area occupied by forest plantations of Eucalyptus and Pinus in Brazil totaled $6,510,693 \mathrm{ha}$, which $73 \%$ corresponding to the area of Eucalyptus and $27 \%$ to Pinus.

In Brazil, a native species that is attracting increas ing interest in timber companies and producers, main ly due to its rapid growth, is Schizolobium amazonicum, also known as

* Corresponding author:

alchristo foro@y ahoo.com.br (André L. Christoforo)

Published online at http://journal.sapub.org/ijme

Copyright (C) 2013 Scientific \& Academic Publishing. All Rights Reserved
Paricá. Belonging to the Leguminosae family, it is native from Bolivia, Colombia, Costa Rica, Ecuador, Honduras, Mexico and Peru[4]. In Brazil, the species has a wide geographical distribution, being found not only in the South Region. According to ABRAF- Brazilian Association of Planted Forest Producers[3], the total area planted with Paricá only in the states of Pará, Maranhão and Tocantins in 2011 was approximately 85 ha.

Paricá wood is very used to manufacture veneers for plywood, pulp and products of the construction market, as ceilings, doors, panels, decorative veneer, fu rniture, fixtures and structures [5-8].

According to Souza[9], Paricá is a species that has low natural durability, being susceptible to fungus, termites, wood decay and insects. Therefore, a preservative treat ment is necessary to prolong the life of such timber.

Main treatments for wood preservatives used in Brazil are the CCA (chromated copper arsenate) and CCB (chro mated copper borate)[10]. CCA is the most commonly used water soluble preservative worldwide. It is usually employed containing about $19 \%$ copper oxide[11].

CCA is widely used in the treatment of wood that remain in contact with the ground being very effective to protect wood against insects (termites and borers), decay fungi and marine borers. However, environ mental concerns about the use of preservatives have been raised due to the dispersion of copper and arsenic into the environment before the complete fixation of the active ingredients with the possibility of 
contamination of soil and groundwater[10-12].

CCB preservative is an alternative product to CCA, with the difference using of the boron element instead arsenic. Its use has advantages such as low cost compared to newer products launched in the market; reduced leaching of copper and chromium, is environmentally friendly, does not increase the electrical conductivity of wood, is non-corrosive to metals such as carbon steel and aluminum[11].

According to Pinheiro[13], chemical wood preservation is extremely important, as well as being proven and effective against bio deterioration. In some cases, can increase the values of the mechanical properties of wood. In this regard, Rocco Lahr et al.[14] studied the influence of preservation with CCB in hardness of wood (parallel and perpendicular to the grain) from planted forests, Pinus elliottii, obtaining gains in the properties investigated.

Given the potential for reforestation in the country and the growing plantation of Paricá wood in Brazil, studies involving the preservative treatment presenting relevant, can alter the physical and mechanical characteristics of the wood in question.

The aim of this research was to evaluate the influence of treatment with $\mathrm{CCB}$ in the properties: apparent density, parallel and perpendicular hardness to the grain, shear strength, strength and stiffness of parallel compression to the grain of the Paricá wood species.

\section{Material and Methods}

Schizolobium amazonicum or Paricá wood came from seven-year-old plantation, in Parago minas City, state of Pará. For this study were rando mly selected fro $m$ the same lot:

- 12 Paricá CCB treated beams, nominal dimensions $3,5 \mathrm{~cm} \times 10 \mathrm{~cm} \times 100 \mathrm{~cm}$;

- 12 untreated beams, nominal dimensions $3,5 \mathrm{~cm} \times 10 \mathrm{~cm}$ $\times 100 \mathrm{~cm}$

From each beam was removed one specimen for each one of the tests, thus obtaining: 24 specimens for hardness perpendicular and parallel to the grain, 24 specimens for shear test and 24 specimens for compression parallel to the grain. As the beams used had a limit in thickness of $3.5 \mathrm{~cm}$, it became necessary to fit the specimens' dimensions for each test. For apparent density testing entire board was used. The methodology used in the tests to determine the physical and mechanical properties followed the ABNT NBR7190[15] ANNEX B - Projects of wooden structures, the Brazilian Association of Technical Standards, recommendation. All beams were kept in a controlled environment, thereby maintaining $12 \%$ mo isture content. Amsler universal testing machine with a capacity of 25 tons was used to carry out mechanical tests, as shown in Figure 1.

\subsection{Preservative Treatment}

The CCB treatment applied on wood through pressure in autoclave was conducted by the company PREMA SA, located in the city of Rio Claro / SP. The treatment retention was $9.6 \mathrm{~kg}$ of active ingredient $\left(\mathrm{m}^{3}\right)$.
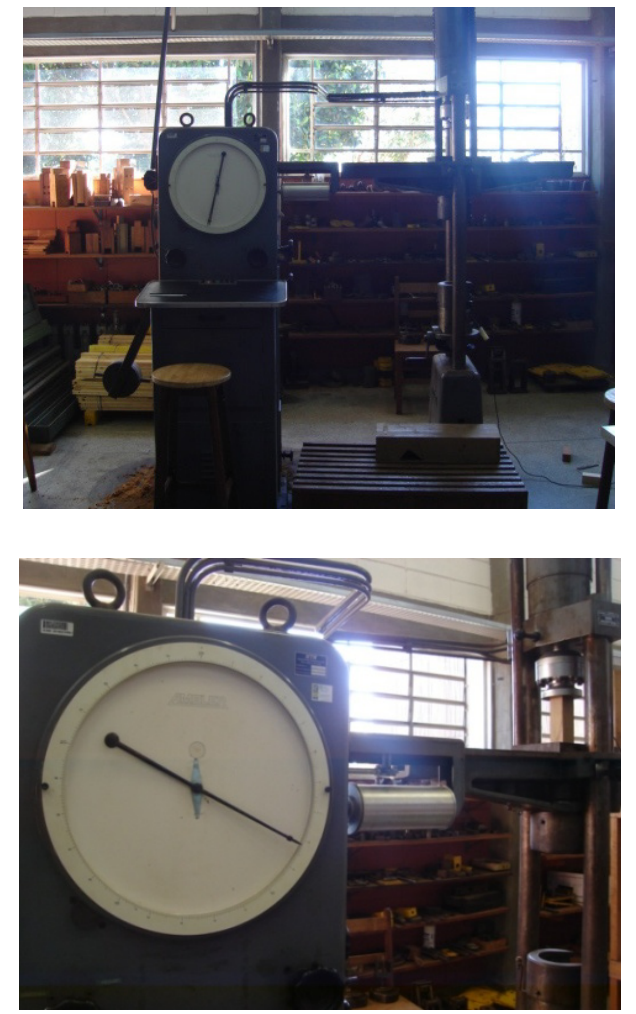

Figure 1. Universal machine of mechanical test, Amsler

\subsection{Apparent Density}

The specimen dimensions for this test were: $35 \mathrm{~mm}$ th ick $\times 100 \mathrm{~mm}$ wide $\times 600 \mathrm{~mm}$ high. Figure 2 shows the apparent density specimen.

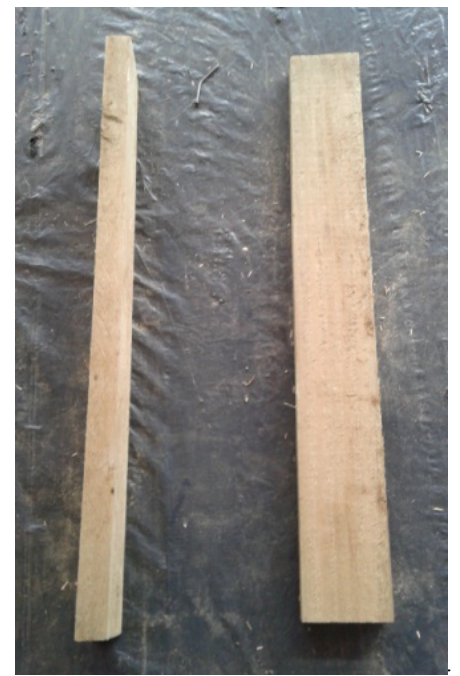

Figure 2. Apparent density specimen

\subsection{Shear Test}

In this test the shear occurs in the direction parallel to the grain. The standard specimen dimensions for this test were: $35 \mathrm{~mm}$ thickness $\times 100 \mathrm{~mm}$ width $\times 60 \mathrm{~mm}$ height; with area dimensions of $35 \mathrm{~mm} \times 50 \mathrm{~mm}$ to be sheared. Figure 3 shows the shear specimen. 


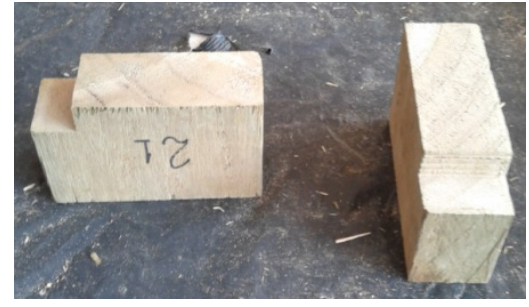

(a)

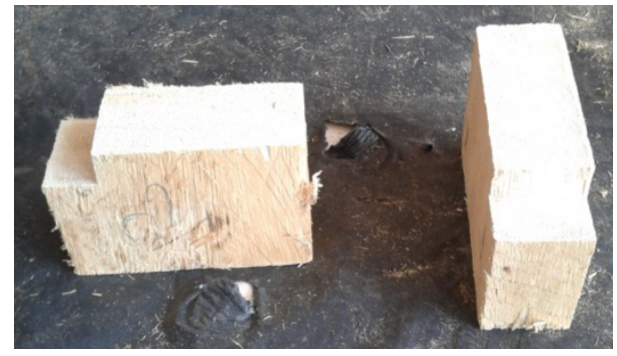

(b)

Figure 3. Shear test. (a) Treated wood; (b) untreated wood

\subsection{Hardness Parallel and Perpendicular to the Grain}

This test was realized on all specimens' faces, resulting in strength values in parallel and perpendicular directions to the grain. The standard specimen dimensions for this test were: $35 \mathrm{~mm}$ thick $\times 100 \mathrm{~mm}$ wide $\times 100 \mathrm{~mm}$ high. Figure 4 shows the hardness specimen.

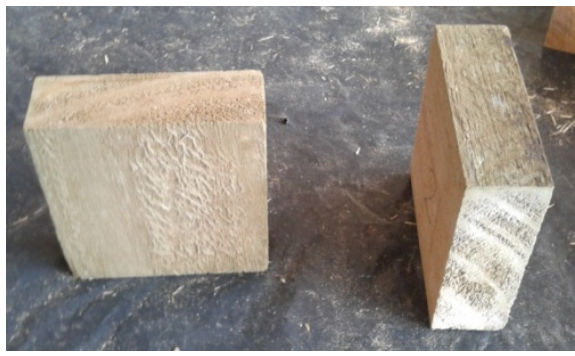

(a)

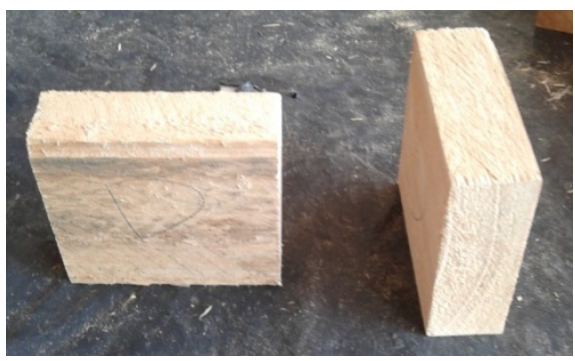

(b)

Figure 4. Hardness test. (a) Treated wood; (b) Untreated wood

\subsection{Compression Parallel to the Grain}

The specimen dimensions for compression parallel to the grain testing[16-22] were: $35 \mathrm{~mm}$ thick $\times 100 \mathrm{~mm}$ wide $\times$ $150 \mathrm{~mm}$ high. Figure 5 shows the compression parallel to the grain specimen. The region measurement to be compressed was performed using deflectometer installed in the center of the specimen.

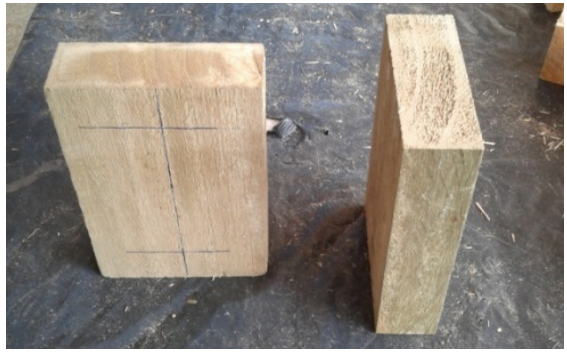

(a)

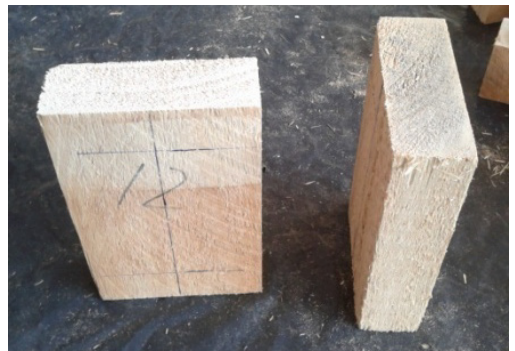

(b)

Figure 5. Compression parallel to the grain test. (a) Treated wood; (b) Untreated wood

\subsection{Statistical Analysis}

The analysis of variance (ANOVA) was used to investigate the influence of the treatment in the properties investigated. The significance level $(\alpha)$ was $5 \%$, considering the null hypothesis $\left(\mathrm{H}_{0}\right)$ the equivalence between the means and the non-equivalence as the alternative hypothes is $\left(\mathrm{H}_{1}\right)$. $\mathrm{P}$-value greater than the significance level involves accepting $\mathrm{H}_{0}$, rejecting it otherwise. To validate the ANOVA model, Anderson-Darling and the Bartlett's tests were used to verify the normality of the distribution and the homogeneity between variances, respectively, both at the 5\% level of significance, considering the null hypotheses as the normality and of the distribution and the equivalence between variances. The null hypothesis is accepted if the P-value obtained in the tests is higher than the significance level, rejecting them otherwise. When significance of the factor was detected by ANOVA, Tukey test for grouping of the averages was employed.

\section{Results}

\section{Apparent density}

The Table 1 shows the results for apparent density tests. $\mathrm{x}_{\mathrm{m}}$ is the average values, $\mathrm{S}_{\mathrm{d}}$ is the standard deviations and $\mathrm{Cv}$ is the coefficient of variation.

Table 1. Apparent density results wood Paricá treated and untreated

\begin{tabular}{ccc}
\hline & \multicolumn{2}{c}{ Apparent density $\left(\boldsymbol{\rho}_{\text {ap }}\right)$} \\
& Untreated & Treate d \\
\hline Specimens $(\mathrm{n})$ & 6 & 9 \\
$\mathrm{X}_{\mathrm{m}}\left(\mathrm{kg} / \mathrm{m}^{3}\right)$ & 383,04 & 407,49 \\
$\mathrm{~S}_{\mathrm{d}}$ & 19,28 & 33,10 \\
$\mathrm{Cv}(\%)$ & 5 & 8 \\
\hline
\end{tabular}


The values obtained for apparent density; with $12 \%$ moisture content for untreated and treated wood were respectively $383.04 \mathrm{~kg} / \mathrm{m}^{3}$ and $407.49 \mathrm{~kg} / \mathrm{m}^{3}$. ANOVA shows that the average for wood Paricá untreated and treated density test are not statistically different from each other (P-value $>0,05$ ).

Thus, it can be assumed that the treatment did not change the Paricá density, differently of the results obtained from the research of Rocco Lahr et al.[14], this had an increase in apparent density by $27 \%$ in the treated wood comparing to wood "in nature".

\section{Shear}

Table 2 presents the shear tests results.

Table 2. Results of shear strength in the direction parallel to the grain treat ed and untreated Paricá

\begin{tabular}{ccc}
\hline & \multicolumn{2}{c}{ Shear strenght $\left(\mathbf{f}_{\mathbf{v} 0}\right)$} \\
\cline { 2 - 3 } & Untreated & Treated \\
\hline Specimens $(\mathrm{n})$ & 8 & 10 \\
$\mathrm{x}_{\mathrm{m}}(\mathrm{MPa})$ & 7,66 & 7,61 \\
$\mathrm{~S}_{\mathrm{d}}$ & 0,78 & 0,55 \\
$\mathrm{Cv}(\%)$ & 10 & 7 \\
\hline
\end{tabular}

ANOVA revealed that the average values of the shear test parallel to the grain of Paricá with treatment and without treatment are not statistically different from each other (P-value $>0,05$ ). Thus, it can be assumed that the treatment did not change the property of shear strength of Paricá wood specie.

Pinheiro[13] obtained, for the Pinus sp. Treated with CCB, shear strength values of $10 \%$ greater than the shear strength from the Pinus sp wood species untreated.

\section{Har dness Parallel and Perpendicular to the Grain}

Table 3 presents the results for hardness tests. Averages values with different letters are statistically different from each other, at a 5\% level of significance.

Table 3. Results of hardness in perpendicular and parallel direction to the grain of the treat ed and untreated Paricá wood specie

\begin{tabular}{|c|c|c|}
\hline \multicolumn{3}{|c|}{$\operatorname{Hardness}\left(\mathbf{f}_{\mathrm{h}}\right)$} \\
\hline & \multicolumn{2}{|c|}{ Perpen dicular to the grain $\left(f_{\mathrm{h} 90}\right)$} \\
\hline & Untreated & Treated \\
\hline Specimens (n) & 9 & 8 \\
\hline $\mathrm{x}_{\mathrm{m}}(\mathrm{MPa})$ & 15,83 & 13,66 \\
\hline $\mathrm{S}_{\mathrm{d}}$ & 2,45 & 2,50 \\
\hline \multirow[t]{3}{*}{$\mathrm{Cv}(\%)$} & 15 & 18 \\
\hline & \multicolumn{2}{|c|}{ Parallel to the grain $\left(f_{h 0}\right)$} \\
\hline & Untreated & Treated \\
\hline Specimens (n) & 7 & 9 \\
\hline $\mathrm{x}_{\mathrm{m}}(\mathrm{MPa})$ & $27,55 \mathrm{~A}^{*}$ & $19,60 \mathrm{~B}^{*}$ \\
\hline $\mathrm{S}_{\mathrm{d}}$ & 4,22 & 2,72 \\
\hline $\mathrm{Cv}(\%)$ & 15 & 14 \\
\hline
\end{tabular}

By ANOVA, it can be assumed that treatment with CCB did not change the hardness in the perpendicular direction to the grain ( $\mathrm{P}$-vale $>0,05)$, this did not occur with the hardness in parallel direction to the grain of Paricá wood specie, present P-value less than the significance level set, showing a decrease of $28.9 \%$ for the wood treated. This fact is probably due to the occurrence of surface cracking in the treatment process under pressure.

Rocco Lahr et al.[14] obtained increases of $58 \%$ to $68 \%$ in hardness parallel and hardness perpendicular to the grain of Pinus elliotii wood specie.

\section{Compression Parallel to the Grain}

Table 3 presents the results for compression tests in parallel direction to the grain.

Table 4. Strength and stiffiness in compression parallel to the grain for the wood treated and untreated

\begin{tabular}{|c|c|c|}
\hline \multicolumn{3}{|c|}{ Compression parallel to the grain } \\
\hline & \multicolumn{2}{|c|}{ Strength $\left(\mathbf{f}_{\mathrm{c} 0}\right)$} \\
\hline & Untreated & Treated \\
\hline Specimens (n) & 8 & 5 \\
\hline $\mathrm{x}_{\mathrm{m}}(\mathrm{MPa})$ & 31,08 & 33,75 \\
\hline $\mathrm{S}_{\mathrm{d}}$ & 2,33 & 1,61 \\
\hline \multirow[t]{3}{*}{$\mathrm{Cv}(\%)$} & 8 & 5 \\
\hline & \multicolumn{2}{|c|}{ Stiffness $\left(\mathrm{E}_{\mathrm{c} 0}\right)$} \\
\hline & Untreated & Treated \\
\hline Specimens (n) & 8 & 9 \\
\hline $\mathrm{x}_{\mathrm{m}}(\mathrm{MPa})$ & 866 & 772 \\
\hline $\mathrm{S}_{\mathrm{d}}$ & 80 & 118 \\
\hline $\mathrm{Cv}(\%)$ & 9 & 14 \\
\hline
\end{tabular}

The strength and stiffness in compression parallel to grain of Paricá wood treated and untreated showed statistical equivalence between means ( $\mathrm{P}$-value $>0,05)$. Thus, it can be assumed that the treatment did not change the strength and stiffness in compression parallel to grain of Paricá. Pinheiro[13] reached increments of $17 \%$ in compressive strength parallel to gra in of Pinus sp. treated with CCA, and average gain of $55 \%$ for the wood treated with CCB.

\section{Conclusions}

In view of what is pointed out in the foregoing, we conclude that the impregnation of CCB in the Schizolobium amazonicum wood specie did not changed the properties apparent density, shear strength, hardness, strength and stiffness in compression parallel to the grain.

The hardness strength parallel to grain was decreased by $28.9 \%$, this fact is probably due to the occurrence of surface cracking in the treatment process under pressure.

\section{ACKNOWLEDGEMENTS}

The authors express their gratitude to $\mathrm{CNPq}$ for granting scholarships, Department of Science and Engineering of Materials, Wood and Timber Structures Laboratory, 
Structural Eng ineering Depart ment and USP São Carlos, that enabled the development of this research. Also we would like to acknowledge PREMA Technology and Trade Company SA for the treatment with $\mathrm{CCB}$ used in the experimental part of this research.

\section{REFERENCES}

[1] Vidaurre G. P. Caracterização anatômica, química e físico-mecânica da madeira de Paricá (Schizolobium amazonicum) para produção de energia e polpa celulósica. Tese (Doutorado). Universidade Federal de Viçosa, Minas Gerais. 89p, 2010.

[2] Calil Neto, C. Madeira laminada colada (MLC): controle de qualidade em combinações espécie-adesivo-tratamento preservativo. Dissertação (mestrado), Universidade de São Paulo, São Carlos, São Paulo. 118p, 2011.

[3] Associação Brasileira de Produtores de Florestas Plantadas. Anuário Estatístico da ABRAF, 45p., 2010.

[4] Carvalho, P. E. R. Paricá Schizolobium amazonicum. Embrapa: Circular Técnico. 8p, 2008.

[5] Almeida D. H.; Scaliante R. M.; Macedo L. B.; Macêdo A. N.; Calil Junior C. Madeira laminada colada (MLC) da espécie Paricá. Madeira Arquitetura e Engenharia 12 (3): 71-82, 2010.

[6] Siviero, M. A.. Paricá: a vedete do reflorestamento. Diário do Pará, Belém, entrevista regional jan eiro: p. A-8, 2006.

[7] Souza, D. B. de; Carvalho, G. S.; Ramos, E. J. A. Paricá Schizolobium amazonicum Huber $x$ Ducke. Informativo Técnico Rede de Sementes da Amazônia 13:2p., 2005.

[8] Terezo, R. Construções Verdes: A temática sustentabilidade chegou a construções e começa a se verificada em exemplos locais. Revista Pará Industrial 18: 14-15, 2011.

[9] Souza, C. R.; Rossi, L. M. B.; Azevedo, C. P.; Vieira, A. H. Paricá: Schizolobium parahyba var. amazonicum (Huber x Ducke) Barneby. Embrapa: Circular Técnico. 12 p., 2003.

[10] Bertolini, M. S. Emprego de resíduos de Pinus sp. tratado com preservante $\mathrm{CCB}$ e resina poliuretana na produção de chapas de partículas homogêneas utilizando resina poliuretana à base de mamona. Dissertação (mestrado), Universidade de São Paulo, São Carlos, São Paulo. 129p, 2011.
[11] Moreschi, J. C. 2011. Produtos preservantes de madeira. (online) <http://engmadeira.yolasite.com/resources.pdf $>$. Consulted: 23 fev. 2012.

[12] Silva, J. C. Madeira preservada e seus conceitos. Revista da Madeira, 2007

[13] Pinheiro, R. V. Influência da preservação contra a demanda biológica em propriedades de resistência e de elasticidade da madeira. Tese (doutorado), Universidade de São Paulo, São Carlos, São Paulo. 187p, 2001

[14] Rocco Lahr F. A.; Fernandes R.; Bertolini M. S. Influência da preservação com CBB na dureza da madeira de Pinus sp. In: Congresso Brasileiro de Ciên cias e Engenharia de Materiais, 19, Campos do Jordão. Anais... Campos do Jordão:[s.n]. CD-Rom, 2010.

[15] Associação Brasileira de Normas Técnicas ABNT NBR7190. Projeto de Estruturas de Madeira. Rio de Janeiro, 1997.

[16] Gong, M.; Smith, I. Failure of softwood under static compression parallel to grain. Journal of the Institute of Wood Science, v 15, n 4, p. 204-210, 2000.

[17] Gindl, W. Comparing mechanical properties of normal and compression wood in Norway spruce: The role of lignin in compression parallel to the grain Holzforschung, v. 56, n. 4, p. 395-401, 2002.

[18] Xavier J, Avril S, Pierron F, Morais J. Novel experimental approach for lon gitudinal-radial stiffness characterisation of clear wood by a single test. Holzforschung; v.61, p. 573-81, 2007.

[19] Benabou, L. Kink band formation in wood species under compressive loading. Society for Experimental Mechanics, Inc., v. 65, p. 647-656, 2008.

[20] Gryc, V.; Vavrcík, H. Variability of spruce (Picea abies[L.] Karst.) compression strength with present reaction wood. Journal of Forest Science, v. 55, n. 9, p. 415-422, 2009.

[21] Silva, D. A. L. Rocco Lahr, F. A.; De Faria, O. B.; Chahud, E. Influence of wood moisture content on the modulus of elasticity in compression parallel to the grain Materials Research, v. 15, n. 2, p. 300-304, 2012.

[22] Xavier, J; Jesus, A. M. P.; Morais, J. J. L.; Pinto; J. M. T. Stereovision measurements on evaluating the modulus of elasticity of wood by compression tests parallel to the grain. Construction and Building Materials, v. 26, p. 207-215, 2012. 